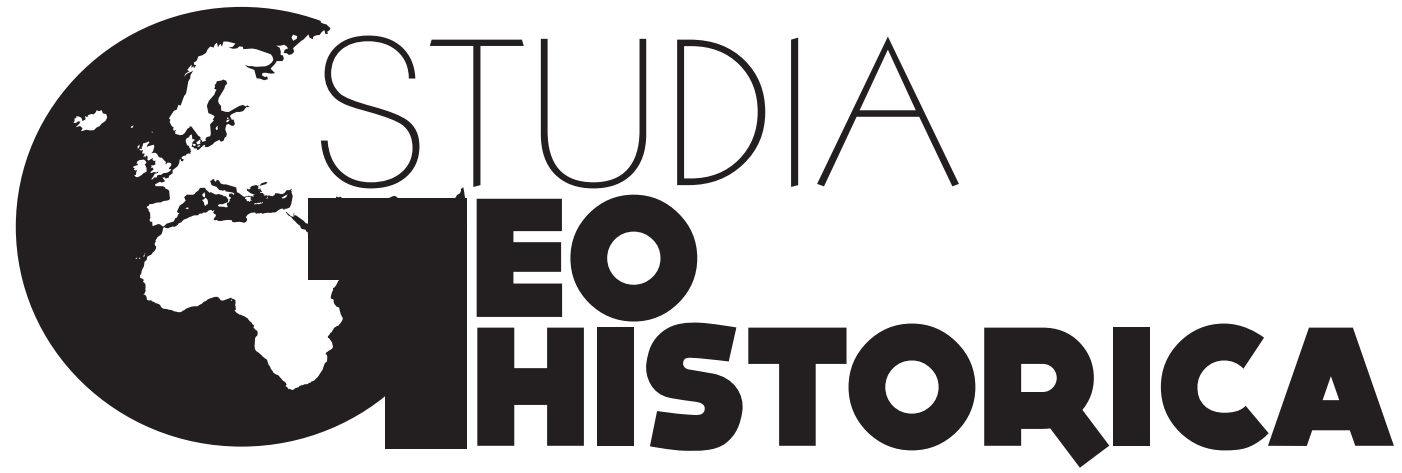

NR 04|2016 ROCZNIK HISTORYCZNO-GEOGRAFICZNY

Fundacja Centrum GeoHistorii • Instytut Geodezji i Kartografii • Instytut Historii KUL

Instytut Historii i Stosunków Międzynarodowych US • Zespół Historii Kartografii przy Instytucie Historii Nauki PAN Biblioteka Główna Uniwersytetu Szczecińskiego 


\section{STUDIA GEOHISTORICA. Rocznik historyczno-geograficzny}

\section{Redakcja}

Bogumił Szady (redaktor naczelny), Beata Konopska, Radosław Skrycki, Tomasz Związek (sekretarz redakcji), Tomasz Panecki

\section{Redakcja językowa i korekta}

Konrad Byzdra

\section{Tłumaczenia}

autorzy, Julia Szołtysek

\section{Rada Naukowa}

Zdzisław Budzyński (Rzeszów), Andrzej Janeczek (Warszawa), Tomasz Jurek (Poznań), Keith Lilley (Belfast/Wielka Brytania), Andrew Pernal (Brandon/Kanada), Tadeusz Siwek (Ostrawa/Czechy), Rostysław Sossa (Kijów/Ukraina), Grzegorz Strauchold (Wrocław), Robert Šimůnek (Praga/Czechy)

\section{Recenzenci tomu 4}

Wojciech Chudziak, Martyna Deszczyńska, Zbigniew Górczak, Maria Jankowska, Iwona Jażdżewska, Andrzej Klonder, Anna Kołodziejczyk, Andrzej Kopiczko, Małgorzata Elżbieta Kowalczyk, Adam Kozak, Joanna Kumor-Mielnik, Mieczysław Kunz, Dariusz Lorek, Wojciech Mielewczyk, Grzegorz Myśliwski, Wiesław Nowosad, Piotr Pabjanek, Marek Radoch,

Małgorzata Rutkiewicz-Hanczewska, Francesco Somaini, Péter Szabó, Piotr Werner, Filip Wolański

\section{Redakcja map}

autorzy, Tomasz Panecki

\section{Adres Redakcji}

Fundacja Centrum GeoHistorii

Redakcja Studia Geohistorica

05-082 Stare Babice, ul. Gen. Tadeusza Kutrzeby 4

\section{Strona internetowa}

studiageohistorica.pl

Wersja drukowana (papierowa) jest wersją pierwotną rocznika Studia Geohistorica

\section{Współwydawcy rocznika}

Biblioteka Główna Uniwersytetu Szczecińskiego, Fundacja Centrum GeoHistorii, Instytut Geodezji i Kartografiii, Instytut Historii Katolickiego Uniwersytetu Lubelskiego Jana Pawła II, Instytut Historii i Stosunków Międzynarodowych Uniwersytetu Szczecińskiego, Zespół Historii Kartografii przy Instytucie Historii Nauki PAN

Rocznik wydawany pod patronatem Komisji Geografii Historycznej przy Polskim Towarzystwie Historycznym Projekt okładki: Jacek Młodożeniec Ilustracja na okładce: Kalisz - Plan miasta i przyległej okolicy autorstwa Ludwiga von Bröckera z 1802 r. Skład i łamanie: Artur Hamryszczak

(C) Copyright by Fundacja Centrum GeoHistorii

ISSN 2300-2875

Nakład 100 egz.

Warszawa 2016 


\section{Spis treści • Contents}

\section{Tradycje geografi historycznej • Traditions of historical geography}

\section{Ludomir Sawicki}

Geografia a krajoznawstwo

(uwagi wstępne Beata Konopska, opracowanie Beata Konopska)

\section{Stanisław Herbst}

Prace nad „Atlasem historycznym Polski”

(uwagi wstępne Henryk Rutkowski, opracowanie Henryk Rutkowski).

\section{Artykuty $\bullet$ Articles and theses}

\section{Elżbieta Kowalczyk-Heyman}

Czym były mazowieckie "płozy"? (uwagi wstępne)

What were the Masovian "płozy"? (Preliminary Remarks)

\section{Robert Klimek}

Ślady średniowiecznej granicy Warmii między Reszlem a Świętą Lipką

Traces of the Medieval Border of Warmia between Reszl and Święta Lipka

\section{Ewa Ziółek}

Relacja Grzegorza Piramowicza o osuszaniu Bagien Pontyjskich za pontyfikatu Piusa VI

Grzegorz Piramowicz's Account of Draining the Pontian Marshes during

the Pontificate of Pope Pius VI

\section{Krzysztof Boroda}

Wpływy z czopowego jako wskaźnik lokalnego zróżnicowania poziomu produkcji

piwa pełnego w miastach Królestwa Polskiego w latach 60. XVI w.

Income from Czopowe as an Indicator of Regional Diversity of Full Beer

Production in the Cities of the Polish Crown in the 1560s

\section{Xavier Rochel}

The End of Gaps and Heathlands in French National Forests, $19^{\text {th }}$ Century.

A Case Study Based on Forest Management Plans

Zanik polan i wrzosowisk we francuskich lasach państwowych w XIX w.

Studium przypadku na podstawie planów zarządzania lasami

\section{Tomasz Figlus}

Typy morfogenetyczne wsi w środkowej Polsce

Morphogenetic Types of Rural Settlements in Central Poland. 
Tomasz Babczyński, Tomasz Kubik, Roman Ptak, Grzegorz Strauchold GIS as a Tool to Analyze the History of Silesia and the Changes in its Political (and Cultural) Geography GIS jako narzędzie do analizy historii Śląska oraz zmian w jego geografii politycznej i kulturowej..

\section{Mateusz Zawadzki}

"Tabella miast, wsi i osad Królestwa Polskiego" jako źródło do badań nad strukturą parafialną województwa lubelskiego

The "Tabella of Towns, Villages and Settlements of the Kingdom of Poland" as the Source for Research into the Parochial Structure of the Lublin Voivodeship

Anna Paulina Orłowska, Bartosz Nowożycki, Grzegorz Pac Handel wołami na terenie Wielkopolski i Śląska w świetle szesnastowiecznego spisu jarmarków i komór celnych The Trade in Oxen on the Territory of the Greater Poland and Silesia in the Light of the $16^{\text {th }}$ Century Description of Annual Fairs and Toll Houses

\section{Recenzje i omówienia $・$ Reviews and discussions}

Historical Atlas of Poland in the $2^{\text {nd }}$ half of the $16^{\text {th }}$ Century: Voivodeships of Cracow, Sandomierz, Lublin, Sieradz, Łęczyca, Rawa, Płock and Mazovia, ed. by Marek Słoń; transl. by Agata Staszewska; Martha A. Brożyna, Peter Lang Edition, Frankfurt am Main 1973-[2014], 4 volumes, XXIX + 1597 pp., illustrations, 27 folded maps

(Alexei Frolov)

Magdolna Szilágyi: On the Road: The History and Archaeology of Medieval Communication Networks in East-Central Europe, Budapest 2014

(Archeolingua Series Minor, 35),

Ss. 254, 89 il. (w tym 30 map i 4 plany miast)

(Ewelina Siemianowska).

The World in a Mirror, Word Maps from the Middle Ages to the Present Day, ed. Jan Parmentier, Museum aan de Stroom, Antwerp 2015, ss. 192, il. $150+25$ (Lucyna Szaniawska)

Kartografia morska i krain nadmorskich, red. R. Skrycki, Instytut Historii

i Stosunków Międzynarodowych Uniwersytetu Szczecińskiego,

Zespół Historii Kartografii Instytutu Historii Nauki PAN, Szczecin 2014;

$24 \times 17$ cm, ss. 204, 54 ryc., 4 tab.

(Jan Rutkowski) 
Алексей А. Фролов, Нина В. Пиотух: Исторический атлас Деревской пятины Новгородской земли (по писцовым книгам письма 1495-1496 годов). В 3 томах: Москва-Санкт-Петербург, Альянс-Архео, 2008.

Т. 1: Исследование и таблицы, ss. 368;

Т. 2: Атлас и справочные материалы, ss. 272;

T. 3: Уездные планы последней четверти XVIII века, ss. 266

(Rostysław Sossa).

Nazwy miejscowe Polski. Historia. Pochodzenie. Zmiany, t. 10-12 (Ra-Rż), red. K. Rymut, B. Czopek-Kopciuch, U. Bijak, [autorzy haseł: U. Bijak, E. Borysiak, J. Chłądzyńska, B. Czopek-Kopciuch, P. Dudek, A. Galasińska, W. Makula-Kosek, I. Nobis, R. Przybytek, P. Swoboda, U. Wójcik, K. Zawodzińska-Bukowiec, Z. Zierhoffer], Polska Akademia Nauk. Instytut Języka Polskiego, Kraków 2015, ss. 160 (t. 10), 146 (t. 11), 168 (t. 12) (Ewa Oronowicz-Kida).

Kit Mayers: The First English Explorer. The Life of Anthony Jenkinson (1529-1611) and his Adventures on Route to the Orient, Devon 2015, ss. 366

(Krystyna Szykuła).

\section{Komunikaty $i$ sprawozdania $\bullet$ Communiques and reports}

Konferencja „Przestrzenne aspekty historycznych badań demograficznych, społecznych i gospodarczych (do 1945 r.)" - Pobierowo, 21-23 października 2015 r.

(Michał Gochna)

„European Social Science History Conference” - Walencja (Hiszpania),

30 marca-2 kwietnia $2016 \mathrm{r}$.

(Michał Gochna)

Zebranie naukowe polskiej sekcji European Society for Environmental History - Warszawa, 16 stycznia $2016 \mathrm{r}$.

(Piotr Guzowski)

„Mapa jako narracja interpretacyjna”. XXIX Ogólnopolska Konferencja Historyków Kartografii - Wrocław, 24-26 września $2015 \mathrm{r}$.

(Jerzy Ostrowski)

Sprawozdanie z konferencji „Województwo poznańskie w XVI w.” - Kościan, 1 lipca 2015 r.

(Michał Stomski).

Sprawozdanie z konferencji „Geografia historyczna. Wyzwania przyszłości” - Łódź, 11-12 czerwca 2015 r.

(Magdalena Deptuła). 204 
Spis treśsi

Pro memoria

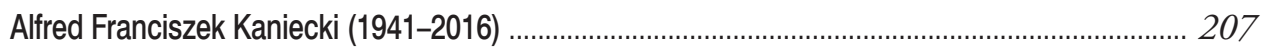

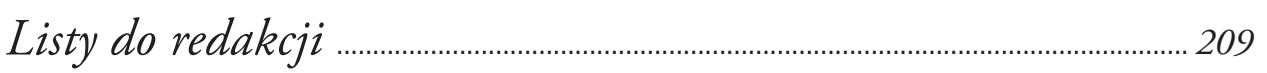

Informacja dla autorów • Guidelines for Authors .................................................... 210 


\title{
Relacja Grzegorza Piramowicza o osuszaniu Bagien Pontyjskich za pontyfikatu Piusa VI
}

\author{
Ewa M. Ziółek
}

Bagna zwane Błotami Pontyjskimi leżą w centralnej części Półwyspu Apenińskiego i zajmują powierzchnię ok. $700 \mathrm{~km}^{2}$. Mają ok. 50 km długości, natomiast ich szerokość dochodzi do $20 \mathrm{~km}$ (zob. mapa 1). Od średniowiecza znajdowały się w południowej części Państwa Kościelnego, przy granicy legacji papieskich z Królestwem Neapolu, pomiędzy Apeninami a Morzem Tyrreńskim oraz miastami Ninfa i Terracina. Ten najbardziej żyzny teren we Włoszech, leżący częściowo $\mathrm{w}$ depresji, poddawano procesom osuszania od czasów pierwszego stałego osadnictwa Wolsków, a zatem od ponad dwóch tysięcy lat ${ }^{1}$. Za pierwsze faktyczne regulacje stosunków wodnych na tym obszarze przyjmuje się działalność cenzora Appiusza Klaudiusza Ślepego w 312 r. przed Chr., której skutkiem było zbudowanie słynnej via Appia. Prace melioracyjne kontynuowane były w czasach republiki rzymskiej, cesarstwa, pod rządami króla Ostrogotów Teodoryka Wielkiego, a potem wielu papieży - od Honoriusza III na pocz. XIII w. po Urbana VIII i Innocentego $\mathrm{X}$ w wieku $\mathrm{XVII}^{2}$. Wszystkie te prace miały dwojaki cel. $Z$ jednej strony chodziło o zdobycie nowych żyznych gruntów pod uprawę roli, z drugiej zaś - o poprawę warunków sanitarnych ludności, której szczególnie dawały się we znaki epidemie malarii.

Pius VI (Giovanni Antonio Braschi, 17171799) zasiadł na tronie Piotrowym w 1775 r.

\footnotetext{
W polskiej literaturze problematykę tę wzmiankowano rzadko i jedynie zdawkowo. Więcej informacji, zarówno o geografii i geologii, jak też historii Btot Pontyjskich, zob.: L. Serva, F. Brunamonte, Subsidence in the Pontina Plain, Italy, „Bulletin of Engineering, Geology and the Environment”, 66, 2007, s. 125-134; R. Casa i in., Assessing Crop Water Demand by Remote Sensing and GIS for the Pontina Plain, Central Italy, „Water Resources Management", 23, 2009, s. 1685-1712; La storia della bonifica pontina (www.bookomag.net/librarypdf/la-storia-della-bonifica-pontina-81274/, dostęp: 10 czerwca 2015).

2 La storia della bonifica.

3 Warto zauważyć, że literatura dotycząca tego aspektu działalności Piusa VI jest niezwykle skromna, szczególnie polskojęzyczna. Praktycznie tylko wzmiankuje się te kwestie, niekiedy zresztą błędnie. Mieczysław Żyw-
}

i od początku pontyfikatu interesował się osuszeniem Błot Pontyjskich, głównie ze względów ekonomicznych ${ }^{3}$. Zasadniczy ciężar finansowy tego przedsięwzięcia miała ponieść Kamera Apostolska, jednak papież szybko zorientował się, że główną przeszkodę będą stanowić niejasne stosunki własnościowe i interesy poszczególnych rodzin (np. hrabiów Gaetani). Niemniej utwierdziwszy się w swoim postanowieniu, zdecydował ściągnąć do Rzymu najlepszych hydraulików. Zrobił to za pośrednictwem kard. Ignazia Boncompagniego, legata papieskiego w przedsiębiorstwie wodnym w prowincji Bolonia. W ten sposób na dwór papieski przybyli bolończycy Gaetano Rappini oraz Ludovic Benelli. Mając wsparcie prawnego komisarza papieża Giulia Sperandiniego, na jesieni 1777 r. Rappini mógł przystąpić do prac, które obejmowały najpierw oczyszczenie $\mathrm{z}$ roślinności i naprawę starych kanałów. Główną rolę w odbiorze wody, która spływała z obszaru bagiennego, miał pełnić nowo przekopany kanał Linea Pia, przebiegający wzdłuż via Appia. Docelowo miał on umożliwić ponowne otwarcie Terraciny jako portu Rzymu poprzez umożliwienie żeglugi nowym kanałem. Prace trwały do lat 90. XVIII w., m.in. z uwagi na konieczne przerwy w okresie letnim, spowodowane zagrożeniem malarią. Już w $1781 \mathrm{r}$. błota zostały uwolnione od nadmiaru wody i papież udał się w podróż inspekcyjną.

czyński umieścił np. omawiany obszar nad Adriatykiem! M. Żywczyński, Włochy nowożytne 1796-1945, Warszawa 1971, s. 33. Wydaje się, że dla wielu badaczy wszelkie inne formy działalności Piusa VI - na niwie gospodarczej, kulturalnej itp. - przykryły wielkie wyzwania epoki: józefinizm, dyskusja z filozofią oświecenia, a szczególnie - rewolucja francuska, która pociagnnęła za sobą dramatyczny koniec pontyfikatu tego papieża. Por.: Z. Zieliński, Papiestwo i papieże dwóch ostatnich wieków, Warszawa 1983, s. 40-80. Franz Xavier Seppelt i Klemens Löffler skupili się w swej publikacji wyłącznie na sprawie rewolucji. F.K. Seppelt, K. Löffler, Dzieje papieży od początku Kościoła do czasów dzisiejszych, t. 4, Poznań 2004, s. 19-28. Nieco podstawowych wiadomości zawiera biogram Piusa VI w: Enciclopedia dei papi, t. 3, Roma 2000, s. 492-509 (o osuszaniu Btot Pontyjskich zob. s. 497-500). 
Do Terraciny przyjeżdżał też w następnych latach, aż do roku 1791. Później wydarzenia polityczne przyczynity się do wstrzymania prac, a zainteresowanie Piusa VI tą inwestycją zmniejszyło się. Mimo że nie ukończono wszystkich założonych w projekcie prac, to znaczna część obszaru została osuszona i oddana pod uprawę. Stałą bolączkę stanowił jednak nadmiar wody, której nie był w stanie odbierać główny kanał ${ }^{4}$.

Omawiana inwestycja odbiła się dość głośnym echem w Europie. Wielu podróżników, którzy zawitali w tym czasie do Państwa Kościelnego, udawało się w podróż do Królestwa Neapolu przez starożytną via Appia, aby przekonać się o postępie prac. Niektóre z pozostawionych przez nich opisów tych działań zdradzają całkowity brak znajomości problematyki i są raczej przywołaniem ciekawostki z podróży ${ }^{5}$. Zupełnie inny charakter mają dość obszerne wzmianki o osuszaniu błot w relacji Augusta Moszyńskiego $^{6} . Z$ jednej strony zają się on opisem zabytków, które wydobyto podczas prac, i zachwycał się żyznością gleb, ale z drugiej zwracał uwagę na techniczne mankamenty przedsięwzięcia. Przede wszystkim zauważyl, że część omawianego obszaru jest depresją. Przewidywał wobec tego, że w bliżej nieokreślonym czasie prace zakończą się fiaskiem, i postulował wybudowanie dużego kanału obwodowego, który zbierałby wody i odciążał Linea Pia?.

\footnotetext{
${ }^{4}$ Całkowite osuszenie Błot Pontyjskich nastapiło w XX w. La storia della bonifica. Inną kwestią byly ciągle nabrzmiałe problemy własnościowe, szczególnie gdy papież obdarzał odzyskanymi gruntami członków swojej rodziny. Enciclopedia dei papi, s. 499-500

${ }^{5}$ Pamiętnik księżny Daszkow damy honorowej Katarzyny II cesarzowej Wszechrosji, ttum. E. Wassongowa, Kraków 1982, s. 188; M. Dąbrowska, Włochy oczami podróżników rosyjskich czasów Oświecenia (Nikotaj Lwow i Jekatierina Daszkowa), „Rusycystyczne Studia Literaturoznawcze", 23, 2013, s. 20. Także większość polskich podróżników, którzy udawali się do Italii w XVIII w., zauważała takie mankamenty, jak utrudnienia w podróży czy niezdrowy klimat, pełen „niezdrowych wyziewów”. Zob.: M.E. Kowalczyk, Obraz Włoch w polskim piśmiennictwie geograficznym i podróżniczym osiemnastego wieku, Torun 2005, s. 124-125, 173. Szkoda jednak, że autorka tej książki nie zauważyła relacji Grzegorza Piramowicza, który w cytowanej publikacji w ogóle nie jest wzmiankowany.

${ }^{6}$ A. Moszyński, Dziennik podróży do Francji i Włoch Augusta Moszyńskiego, architekta JKM Stanisława Augusta Poniatowskiego 1784-1786, wybór i ttum. B. Zboińska-Daszyńska, Kraków 1970, s. 237, 371, 552555.

7 Tamże, s. 415, 554-555; M.E. Kowalczyk, Obraz, s. 173
}

Moszyński to nie jedyny Polak, którego zainteresowało osuszanie Błot Pontyjskich, szczególnie że w XVIII w. na terenie Rzeczypospolitej podejmowano prace melioracyjne, choć najczęściej były to regulacje spławności rzek ${ }^{8}$. Nie możemy zapominać m.in. o projektach kanałów łączących ważne gospodarczo cieki. Bagna Pontyjskie w Italii jeszcze długo interesowały przybyszów, m.in. Józefa Wybickiego oraz polskich legionistów przemierzających omawiany obszar w latach 1798-1799, w trakcie wojny neapolitańskiej?.

Mało znanym opisem tej wielkiej inwestycji jest relacja ks. Grzegorza Piramowicza (1735$1801)^{10}$, być może dlatego, że o jej autorze czytamy najczęściej w kontekście działalności pedagogicznej w Komisji Edukacji Narodowej, a niniejsze źródło wspominane jest jedynie w niektórych jego biografiach. Na pewno nie była to fundamentalna praca, do której autor przywiązywałby znaczącą wagę, a raczej ciekawostka, pokazująca zarówno humanistyczną erudycję, jak i w pewien sposób warsztat naukowy eksjezuity. W połowie lipca 1779 r. sekretarz Towarzystwa do Ksiąg Elementarnych Grzegorz Piramowicz udał się w trwającą ponad rok podróż do Włoch i Francji. Towarzyszył w niej Elżbiecie Potockiej (żonie Ignacego) oraz Aleksandrze i Stanisławowi Potockim ${ }^{11}$. Była to wyprawa służbowa, na którą Piramowicz uzy-

${ }^{8}$ A. Winiecki, A. Drabiński, Melioracje a ochrona przyrody - niezbędny kompromis, w: Ekologiczne aspekty melioracji wodnych, red. L. Tomiatojć, Kraków 1995, s. 109.

9 Józef Wybicki. [Materiały z sesji, Gdańsk 2-3 VI 1972], red. A. Bukowski, Gdańsk 1975, s. 327. Jest to głos w dyskusji znawcy tematyki legionowej prof. Jana Lubicz-Pachońskiego.

${ }_{10}$ Biblioteka Narodowa w Warszawie [dalej: BN], rkps II 6845, Krótka wiadomość o bagnach pontyńskich i osuszeniu onychże przez dzisiejszego papieża przedsięwziętym spisana podczas podróży na toż miejsce R. 1780. G.P., s. 1-34.

11 Piramowicz był mocno związany z rodziną Potockich, szczególnie z Ignacym, od którego po kasacie zakonu jezuitów uzyskał wsparcie w postaci prezenty na probostwo w Kurowie koło Lublina. W końcu marszałek litewski uczynił go swoim głównym współpracownikiem w Komisji Edukacji Narodowej. Zob.: E. Aleksandrowska, Grzegorz Piramowicz, w: Polski stownik biograficzny, t. 26, red. E. Rostworowski, Wrocław-Warszawa-Kraków-Gdańsk-Łódź 1981, s. 529-536; Grzegorz Piramowicz i jego epoka, red. K.A. Boreczek, A.A. Witusik, Kurów 2001; S. Gawlik, Grzegorz Piramowicz - idee, stowa, czyny, Opole 2006; K. Mrozowska, Grzegorz Piramowicz jako sekretarz Towarzystwa do Ksiagg Elementarnych (1775-1787), „Studia i Materiały 
skał oficjalny urlop z KEN ${ }^{12}$ oraz polecenie zapoznania się z systemami edukacyjnymi w zwiedzanych krajach i nawiązania tam kontaktów naukowych. Dla pełnej jasności oczekiwania te zostały sprecyzowane $\mathrm{w}$ specjalnej instrukcji ${ }^{13}$. Dość szyblko Piramowicz zorientował się, że elity naukowe Italii w niewielkim stopniu zainteresowane są działalnością KEN. Niemniej on sam poznał wielu ciekawych ludzi, zwiedził istotne dla kultury i nauki miejsca oraz zawart wiele interesujących znajomości ${ }^{14}$. Sporządzał też dwojakiego rodzaju sprawozdania z podróży: szczegółowe raporty przesyłane na ręce prezesa KEN bp. Michała Jerzego Poniatowskiego oraz mniej oficjalne, przeznaczone dla Ignacego Potockiego ${ }^{15}$.

Z zachowanych pism do Potockiego pochodzi prezentowana relacja o osuszaniu Bagien Pontyjskich, przechowywana w Bibliotece Narodowej w Warszawie. Niewątpliwie mamy tu do czynienia czystopisem, opatrzonym datą roczną i inicjałami autora. Dzieło to jest starannym opracowaniem naukowym zagadnienia, opatrzonym wieloma przypisami autora, jednakże warunkowanym poziomem jego wiedzy. Relację można podzielić na dwie części - historyczną i odnoszącą się do współczesności. Jak wynika z treści, nasz podróżnik niezbyt dobrze znał się na zagadnieniach technicznych. Wyraźnie stwierdza, że poprzestał na wyjaśnieniach poznanego osobiście Rappiniego, który oprowadzał go po budowie i wprowadził w kwestie techniczne. Piramowicz nie pozwala sobie zatem na głosy krytyczne, choć ma świadomość, że wcześniejsze próby osuszenia

z Dziejów Nauki Polskiej. Seria A. Historia Nauk Społecznych", 2, 1958, s. 162-200; E.M. Ziótek, Mistrz i jego mecenas. Stowo o wspótpracy Grzegorza Piramowicza i Ignacego Potockiego w dziele edukacji ludu, w: Ród Potockich w odmęcie historii (XVII-XX w.), red. Z. Janeczek, Katowice 2007, s. 463-471; taż, Grzegorz Piramowicz - teoretyk i praktyk pedagogiki polskiego oświecenia, w: Ars Educandi. Żródta, t. 1: Studia z dziejów wychowania $i$ kształcenia od średniowiecza do XIX wieku, red. J. Gwioździk, P.P. Barczyk, Mysłowice 2009, s. 264-273.

12 Protokoty posiedzeń Komisji Edukacji Narodowej 1773-1785, oprac. M. Mitera-Dobrowolska, Wrocław-Warszawa-Kraków-Gdańsk 1973, s. 114.

13 J. Rudnicka, Instrukcja Komisji Edukacji Narodowej z 1779 r. dla Grzegorza Piramowicza podróżującego po Italii, „Przegląd Humanistyczny”, 17 (4), 1973, s. 101-103.

14 Tamże, s. 103; K. Mrozowska, Grzegorz Piramowicz, s. 177-181. Główny nacisk autorka ta położyła na kwestie oscylujące wokół edukacji, natomiast zainteresowania samego Piramowicza były znacznie szersze.
Błot Pontyjskich nie przyniosły efektu. Część poprzedzająca bezpośrednią relację jest popisem erudycji osiemnastowiecznego humanisty, przy czym zgodnie $\mathrm{z}$ duchem epoki na równi traktuje rozprawy naukowe współczesnych i starożytnych uczonych i pisarzy. Powołuje się zatem na $\mathrm{Hi}$ storię naturalna Pliniusza, Odyseje, Eneide, dzieła poetyckie Horacego (w tym wypadku chodzi o opis podróży poety z Rzymu do Brundyzjum), Geografie Strabona, Historie gockq Prokopiusza z Cezarei, prace Dionizego z Halikarnasu, Tytusa Liwiusza, Plutarcha, Swetoniusza, ale też na bardziej współczesne sobie dzieła, jak choćby album inskrypcji rzymskich Grutera ${ }^{16}$ czy ówczesne wypisy źródłowe i biografię Teodoryka Wielkiego. Relacja była przez Piramowicza uzupełniana, o czym sam wspomina pod koniec tekstu: „Po napisaniu tej wiadomości zdarzyło mi się dostać i czytać Latium Athanasii Kircheri” ${ }^{17}$. Abstrahując od wartości naukowej dzieł Kirchera ${ }^{18}$, pokazuje nam to naukowe podejście Piramowicza do badanego zagadnienia i dążenie do całościowego zaprezentowania problemu. Wydaje się jednak, że najbardziej wartościowy jest opis Błot Pontyjskich dokonany z autopsji, a szczególnie prezentacja zabytków wydobytych przy okazji prac melioracyjnych oraz zrelacjonowanie założeń technicznych przyświecających papieskim inżynierom. Spotkanie z Gaetanem Rappinim nie było więc czysto kurtuazyjne. Piramowicz podaje szczegółowe dane pomiarowe kanałów i założenia projektu. Wspomina też o planach utworzenia muzeum, które eksponowałoby

\footnotetext{
15 Tamże, s. 178.

16 Inscriptiones antiquae totis orbis romani. In corpus absolutissimum redacte ingenio ac cura Jani Gruteri. Auspiciis Josephi Scalgeri ac Marci Velseri, [b.m.w.] 1601

17 BN, rkps II 6845, s. 23; Athanasii Kircheri è Soc. Jesu, Latium. Id est, nova et parallela Latii tum veteris tum novi descriptio. Qua quaecunque vel natura, vel veterum romanorum ingenium admiranda effecit, geographico-historico-physico ratiocinio, iuxta rerum gestarum, temporumque seriem exponitur et enucleatur, Amsterdami 1671.

18 Był on wprawdzie jednym z pierwszych uczonych przekonanych, że choroby powodują drobnoustroje, oraz badaczem kultury chińskiej i starożytnego Egiptu, jednak z drugiej strony zarzuca mu się przeintelektualizowanie dzieł. Zob.: M. Pieczyński, Jezuicia ars combinatoria. O poszukiwaniu uniwersalnej metody naukowej w drugiej połowie XVII wieku (https:// depot.ceon.pl/bitstream/handle/123456789/3129/Jezuici-a-ars-combinatoria-repo.pdf?sequence $=1 \&$ isAllowed $=y$, dostęp: 16 kwietnia 2016).
} 
wydobyte podczas prac antyczne zabytki. Ich los był zresztą bliski podróżnikowi, który z zachwytem opisywał ruiny starożytnej łaźni, słupy milowe cezarów itp.

Autor dołączył do tekstu relacji aneksy A, B i C, przy czym $\mathrm{C}$ jest powtórzeniem aneksu A i wobec tego został pominięty w edycji.

Rękopis zamyka krótki, czterostronicowy dodatek zapisany prawdopodobnie przez Ignacego
Potockiego, uzupełniający relację o dotyczący Błot Pontyjskich wypis z publikacji prof. Simondsa z Cambridge z 1796 r., będący opisem podróży Anglika po Italii. Został on tu pominięty, ponieważ nie jest dziełem Piramowicza.

W prezentowanym poniżej tekście dokonano nieznacznych zmian: uwspółcześniono interpunkcję i ortografię, zwłaszcza zapis liter $i, j$ oraz $y$; zachowano oryginalną składnię.

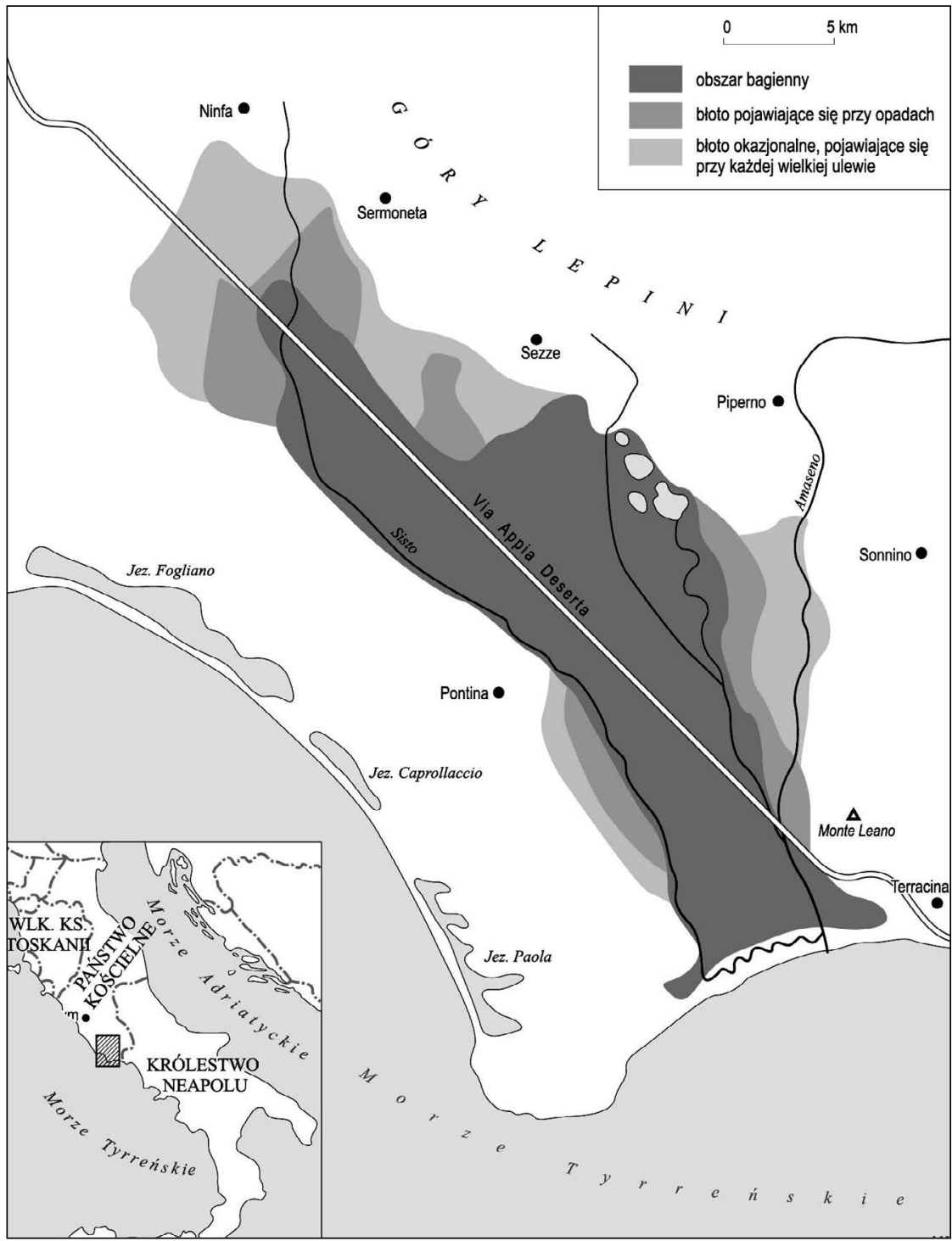

Mapa 1. Btota Pontyjskie w XVIII w., oprac. M. Juran na podstawie ryciny G. Rappiniego z 1778 w: L. Serva, F. Brunamonte, „Subsidence”, s. 127, fig. 2

\section{Studia Geohistorica • Nr 05. 2017}




\section{Krótka wiadomość o Bagnach Pontyńskich i osuszeniu onychże przez dzisiejszego Papieża przedsięwziętym spisana podczas podróży na toż miejsce R. 1780}

\section{G[rzegorz] P[iramowicz]}

I. Uważając naturę i położenie Bagn Pontyńskich, zdaje się, iż ta dolina błotnista jest wulkanem, czyli górą ognistą niegdyś zapadłą. Gatunek ziemi do popiołu podobny, góry bagna otaczające, wody siarczyste, te i inne okoliczności rzeczony domysł utwierdzają. Nie masz wprawdzie nic jasnego o tym przypadku w historiach, ale wyraz Pliniusza choć i daleko, zdaje się oznaczać go w tych słowach: „aliud miraculum a Circeiis palus Pomptina est”. Mówi zaś o owem miejscu, gdzie przywodzi wzmiankę o wyspie cyrcejskiej, jak ją zowie Homer, które teraz ziemią ciągłą jest i zdaje się dawać do domyślenia, że pierwszy cud był złączenie wyspy z ziemią. Co wszystko pochodzić podług wszelkiego podobieństwa mogło z trzęsienia ziemi, zapadnienia wulkanu i gwałtownych powodzi.

Znajduje się po polach kamień dziarstwy ${ }^{1}$ (tophus) skorupa kamienna, która się robi na korzeniach i pieńkach trzcinowych i innych roślin, która służy bardzo przez swoje moc i lekkość do robienia sklepień.

Grunt tamtejszy niewymownie jest żyzny, ziemia czarna i tęga. Uprawiona i zasiana wielki urodzaj przynosi tak dalece, iż kiedy ziarno nie wyda więcej jak około dwadzieścia, rok za nieurodzajny poczytany bywa. Pospolicie nasienie czterdzieści ziarn niesie. Owszem, są świadectwa poważne, iż z jednego ziarna czterdzieści kłosów się rodzi. Zioła nawet wodne czerstwością i mocą swoją w zalanym jeszcze gruncie okazywały tę jego dobroć. Przenoszą żyzność tego gruntu nad żyzność Lombardii, gdyż tam ugorem zostawują rok jeden pola, co i w Kampanii szczęśliwej w niektórych miejscach czynią. Pola zaś Pontyńskie osuszone nigdy nie próżnują. Po zebraniu pszenicy sieje się pszenica turecka, po tej inne ziarna i znowu zaraz w jesieni wraca się zwyczajna siejba. Co wszystko widać na częściach Bagn Pontyńskich osuszonych dawniej przez papieże lub zebrane na ten koniec kompanie. Od stu i więcej lat sieją po kilkadziesiąt tysięcy korcy naszych, nie zostawując roli odłogiem. Dionizy z Halikarnasu ${ }^{2}$ i Tacyt ${ }^{3}$ wysławiają żyzność tego kraju, pierwszy nazywa go gumnem i spiżarnią łacińskiego kraju dla wielkiej obfitości i dobroci zbóż, win, owoców, jarzyn. Niektórzy wywodzą imię miasta Pometia od pomum, jabłko.

Widziałem tej wiosny posadzone różne drzewa, krzewinę bawełny, co wszystko prędki i żywy wzrost bierze. Zawiadowca osuszenia bagn sprowadził z Sycylii trzciny cukrowe, zasadził je mało co przed moją bytnością, jeszcze nie znać były, czy się przyjęły, a dyrektor niepewny, czyli zdrowe doszły, gdyż trochę stęchlizną ciągnęły, o drugich sprowadzeniu zamyślał. Później słyszałem, iż się przyjęcie powiodło.

Klima tamtego miejsca dziwnie ciepłe jest i równie sprzyja wzrostowi drzew i roślin, jako klima najpołudniejszych stron Królestwa Neapolitańskiego. Cytryny i pomarańcze kwaskowate, na otwartem się polu rodzą. Takie jest powietrze Terraciny i okolic jej. Góry od północy leżące ochraniają tamte położenia od zimy.

\footnotetext{
a Plin. Hist. nat. I. 3. Monte Circeo albo Circello, przedtem wyspa za Homera, Odyss. X w. 194, a teraz góra od brzegu morza idąca, Cirocii i Circuius mons. Circeii quondam insula immenso quidem mari circumdata ut creditur Homero, at nunc planitie. Plin. tamże. Było też miasto Wolsków Circeii. Widać jego reszty na tym miejscu, gdzie teraz la Citta Vecchia. ${ }^{1}$ Według Stownika języka polskiego Samuela Bogumiła Lindego (t. 1) dziarstwisty kamień jest materią podobną do piasku gruztowatego - chropowaty. Odpowiada to strukturze wulkanicznego tufu. ${ }^{2}$ Dionizjusz z Halikarnasu (ok. 60-7 przed Chr.) grecki retor i historyk, autor m.in. historii Rzymu do czasów pierwszej wojny punickiej. ${ }^{3}$ Publius (Caius) Cornelius Tacitus (ok. 55-ok. 120), historyk rzymski, w 97 r. konsul, autor m.in. Historiae i Annales.
} 
Bagna same prawie ze trzech stron opasane są górami.

Rozległość Bagn Pontyńskich rozciąga się na dwadzieścia kilka mil długości, a w szerokości największej na 7 lub 8.5 mil włoskich rachować można na jedną milę polską. ${ }^{1}$ Te bagna z południa mają morze i jeziora solne, które się z morzem schodzą, od wschodu górę $\mathrm{S}$. Felice albo Monte Circello, brzeg Terraciny, góry Terracyńskie, Piperno, Sezze, Sermonetta, z północy pagórki ciągnące się od Velletri, a od zachodu pola Cisterny ${ }^{a}$.

Wody z gór spadające, które rozchodząc się i rozlewając, czynią bagna, są te: Amazeno albo Badino, Baudino (Amasenus) rzeka, z strony wschodniej spada z okolic Piperno i prowadzi z sobą inne wody z gór. Ufens albo Portatore poczyna się ku Casae Novae, łączy się z Amazenem i wpada w morze. Ma trzy zrzódła i przeto jest spławną. Cavatella także z wielu zrzódeł wynika poczynających się pod górami Sezze i Sermonetta, a osobliwie z aqua puzza, które ma zapach siarkib, bieży ta rzeka z północy ku południowi prawie obok drogi apiuszowej². Może być, że tym kanałem płynął Horacjusz $^{3}$ w swojej podróży do Brindisi. Nimfa, Nimpha (Nimphaeus), rzeka, która się poczyna w stronie północnych bagn, niedaleko ruin starego miasta Nimfa, wpada w kanał Cavata, którego łoże jest płytkie i nie obejmuje wód za najmniejszym ich przybyciem. Potok zwany Teppia, który jest trochę ku zachodowi niewielki, ale podczas deszczów staje się straszny, ponieważ zbiera w siebie wody z różnych gór idące. Fosso di Cisterna przyczynia się wiele do powodzi. Wychodzi potok z góry Artemisio, przebiega Velletri, Cisterna, bierze w siebie wody różne i wzbiera mocno po wielkich deszczach. Wody te rozchodzą się po środku bagn. Potok wpada częścią w dawne koryto Rio Martino, częścią w drugi fiume antico, z którym gubi się w bagnach, od tego czasu jako groble od Sixtusa $V^{4}$ zrobione pozrywały się. Fosso $S$. Nicolo ma łoże, które rozumieją, że od Augusta zrobio- $^{5}$ ne. Groble pozrywane. Są dwa jeziora i dawnym znane. Jezioro Ponckie, Lacus Pontinus, od miasta Pontia rzeczony, stykający się z Amazenem i Ufentem rzekami, który tak jest zamulony ziemią i błotem z gór zsunionem, że się dawnem i z natury bagnem być zdaje. Drugie jezioro Pomatianus od miasta Pometia dawniej, teraz Lago di Fogliano zwany, blisko góry Cyrcejskiej w ryby obfitujący.

II. Imię Paludi Pontina pochodzi od miasta Wolsków Pometia, Suessa Volscorum, które było ludne i znaczne, nawet przed założeniem Rzymu, na tem, jak mniemaja, miejscu, gdzie dzisiaj jest Mesa albo Mesia. Łacinnicy dawni nazywają go Ager Pontianus, stąd Palus Pometina i Pomptina. Podług Dionizjusza z Halikarnasu ${ }^{c}$ część Lacedemończyków, kiedy Likurg ${ }^{6}$ nowe prawa stanowił, dla surowości onych wyszła z ojczyzny. $\mathrm{Ci}$, po długiem żeglowaniu, chcąc przybić do najpierwszego brzegu, przybyli do Włoch w okolicach pontyńskich. A znalazłszy kraj żyzny i obfity we wszystko, nazwali go Feronia a ferendo, iż wszelkiego gatunku owoce niesie, a boski dla siebie opatrzności ten trefunek przypisując, wystawili Junonie Feronii kościół, gdzie i las jej poświęcony był, jako jest w Wergiliuszu ${ }^{7}$. Ten kościół mianuje Horacjusz w swojej podróży swojej [ss]. Ten kraj po tym, jak się zaludnił, iż liczono w nim miast dwadzieścia i trzy podług Pliniusza ${ }^{8}$ : „a Circeiis Palus pontina est, quem locum viginti trium urbium Mucianus ter consul prodidit"d.

Appius Claudius censor ${ }^{9}$ na lat 310 przed Chr. pierwszy pracował około Bagn Pontyńskich, porobił drogi, kanały, mosty, których ostatki jeszcze zostają. Wojny nadeszłe przerwały roboty

\footnotetext{
${ }^{1} 1$ mila polska wynosita ok. 4,5 km. Piramowicz odnosit się do miar dla Korony ustanowionych na sejmie w $1764 \mathrm{r}$. ${ }^{a}$ Terracine u Wolsków i dawniej

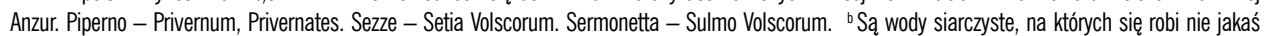
osiadłość. Jest także jeden potok poknyty niby sklepieniem aquaductu i dlatego nazywają go fiume coperto. Czasem się tej ziemi odrywają sztuki na ksztatt wysp pływających. ${ }^{2}$ Chodzi o starożytną via Appia. ${ }^{3}$ Quintus Horatius Flaccus (65-8 przed Chr.), poeta rzymski z kręgu Mecenasa, autor Satyr, Pieśni innych utworów. ${ }^{4}$ Sykstus V (1521-1590), Felice Peretti, franciszkanin, papież od 1585 r., reformator kurii rzymskiej i Państwa Kościelnego. ${ }^{5}$ Caius Iulius Caesar Octavianus Augustus ( 63 przed Chr.-14 po Chr.), pierwszy i jeden z najwybitniejszych cesarzy rzymskich, reformator imperium rzymskiego. ${ }^{\circ}$ Dionisi Halicarn. lib. 2. ${ }^{6}$ Likurg (IX lub VIII w. przed Chr.) legendarny twórca ustroju spartańskiego. ${ }^{7}$ Publius Vergilius Maro (70-19 przed Chr.) poeta rzymski, autor m.in. epopei narodowej Eneida. ${ }^{8}$ Caius Plinius Secundus (23-79), Pliniusz Starszy, rzymski pisarz i urzędnik, autor dzieła encyklopedycznego Historia naturalis w 37 ksieggach. dVirgil. Aeneid. VII. 719. v. Horat. lib. 1 sat V Plin. lib. VI. ${ }^{9}$ Appius Claudius Caecus (ok. 360-275 przed Chr.) rzymski polityk, budowniczy pierwszego akweduktu i pierwszej bitej drogi. ${ }^{\circ}$ Sławna jest droga via Appia, która szła z Rzymu aż do Brundisium i miasto od niego założone i nazwane Forum Appii.
} 
i starania. Znowu się odnowiły wylewy i na 158 przed Chry[stusem] trzeba było wiele poprawy. Caethegus consul ${ }^{1}$ przedsięwziął to dzieło, bagna osuszył, role z nich porobił. „Pomptine Paludes a Cornelio Caethego Consule, cui ea provincia evenerat, exsiccatae, agerque ex eis factus est”. Senat w nagrodę dał mu część gruntów wysuszonych, jako świadczy napis znaleziony niegdyś, jako świadczy Ligorius ${ }^{2}$. Roboty w dalszym czasie długo zaniedbane były. Julius Caesar ${ }^{3}$ przedsięwziął zamysł obrócenia ujścia Tybru pod Terracinę dla ułatwienia handlu z Rzymem, dania ścieku Bagnom Pontyńskim i obiecywał między lud pola podzielić. Plutarch ${ }^{4}$, Sweton ${ }^{5}$ i Dio ${ }^{6}$ mówią o tem przedsięwzięciu. August po części wykonał zamysł Juliusza, jako się zdaje wnosić z wierszów Horacjusza: „Regis opus, sterilisque diu palus, aptaque remis / Vicinas urbes alit, et grave sensit aratrum"b.

Lucius Antonius ${ }^{7}$, brat Marka Antoniusza ${ }^{8}$, będąc trybunem pospólstwa, postanowił prawo, które rozkazywało, ażeby grunt pontyński rozdawany był ludowi, chociaż jeszcze nie był w stanie uprawy.

Strabon ${ }^{9}$ mówi o kanale pod Terraciną blisko drogi apiuszowej, ten to sam jest kanał wspomniony od Horacjusza w opisaniu podróży swojej z Rzymu do Brundisium.

$\mathrm{Nerva}^{10}$ cesarz pracował około naprawy drogi apiuszowej. Znaleziono było kilka kamieni milowych tego cesarza z napisami Nerwie. Trajan ${ }^{11}$ syn jego wybrukował na nowo i sprostował też drogę przerzynającą Bagna Pontyńskie, porobił mosty. Droga Trajana rozciągała się od Trepontium do Terraciny na dziewiętnaście mil włoskich, polskich około cztery, który przeciąg potem nazwany [został] decennovium. Kamienie milowe Trajana mają dwojaką mil liczbę, jedną na wierzchu, znaczącą milę pewną z dziewiętnastu, drugą na spodzie, oznaczającą odległość od Rzymu [A].

Za czasów Pliniusza myślano o osuszeniu bagn. Mówiąc ten autor o zielu merois albo inaczej herba aetiopis, której bajecznie przypisywano moc wysuszania błot, rzekł żartem: „Sic centur hodie meroide Pontina Paludes, tantumque agri, suburbanae reddatur Italiae"c. Znajduje się w Gruterze ${ }^{\mathrm{d}}$, napisy Konstantyna $^{12}$, Joviniana ${ }^{13}$, dwóch Teodozych ${ }^{14}$, Arkadiusza $^{15}$ i Honoriusza $^{16}$.

Za upadkiem państwa rzymskiego bagna się wznowiły. Teodoryk ${ }^{17}$, król włoski oddał je Cecyliuszowi Decjuszowi ${ }^{18}$ do wysuszenia. Robota się szczęśliwie udała, jako świadczy napis na kamieniu znajdujący się w kuchni biskupa terracyńskiego, napis położony oryginalnie, którego kopia także znajduje się na placu tego miasta $[\mathrm{B}]$.

Z papieżów, którzy osuszenie błot przedsiębrali, zdaje się być pierwszy Bonifacy VIII ${ }^{19} \mathrm{z}$ familii Gaetanich, książąt Sermonetta, do których wielka część gruntu zalanego należała. Ten około r. 1294 zabrał się do wysuszenia tych bagnisk, rozkazał wszystkie wody wprowadzić w rowy i rznąc jeden wielki kanał dla ściągnienia trzech rzek do Cavati albo do kanału, jak rozumieją, Augusta. Co osuszyło wyższą część między Sermonetta i Sezze, ale wody niższej części nie miały dosyć spadku

\footnotetext{
${ }^{1}$ Cornelius Cethegus (ok. 160 r. przed Chr.), konsul rzymski. TTit. Liv. lib. LXVI. ${ }^{2}$ Chodzi prawdopodobnie o Pirra Ligoria (1512/13-1583), włoskiego architekta, malarza i autora ksiązki Delle antichità di Roma (1553), w której zamieścit odwzorowania rzymskich zabytków. ${ }^{3}$ Gaius lulius Caesar (101-44 przed Chr.), rzymski wódz, polityki pisarz, wielokrotny konsul i dyktator, reformator republiki rzymskiej. ${ }^{4}$ Plutarch z Cheronei (przed 50-po 120), grecki pisarz ifilozof, autor m.in. Żywotów równolegtych - biografii sławnych Greków i Rzymian. ${ }^{5}$ Caius Suetonius Tranquillus (ok. 70-ok. poł. II w.), rzymski historyk, biograf, sekretarz kancelarii cesarza Hadriana, autor m.in. De viris Illustribus, Żywoty cezarów. ${ }^{6}$ Dion z Prusy zw. Chryzostomos, (ok. 40-po 112) grecki retor ifilozof, polityk na dworze cesarza Tytusa, przyjaciel Nerwy i Trajana, autor 78 mów, m.in. Peri basileias uważanej za pochwałę władcy idealnego - Trajana. ${ }^{\circ}$ Horat. Arte Poetica 65, Horat sat. V. ${ }^{7}$ Lucius Antonius (I w. przed Chr.), młodszy brat Marka Antoniusza, trybun ludowy. ${ }^{8}$ Marcus Antonius (ok. 83-30 przed Chr.), rzymski wódz, stronnik Juliusza Cezara. ${ }^{9}$ Strabon (63 przed Chr.-ok. 20 po Chr.), grecki geograf i podróżnik; jego gtówne dzieło to Geographica w 17 księgach. ${ }^{10}$ Marcus Cocceius Nerva (30-98), cesarz rzymski. ${ }^{11}$ Marcus Ulpius Traianus (53-117), adoptowany syn Nerwy, cesarz rzymski od 98 r. ' Plin. hist. nat. lib. XXXVI Cap. IX. W tymże samym czasie Quintilian między materiami szkolnego ćwiczenia wymowy kładzie to pytanie: „An palus pontina exsiccari possit”. " Taki jest napis przyłączony do napisu pod literą A. ${ }^{12}$ Flavius Valerius Constantinus (274-337), Konstantyn Wielki, cesarz rzymski od $306 \mathrm{r}$. ${ }^{13}$ Piramowicz błędnie podał imię heretyka z V w. W tekście powinien być Jowian, właśc. Flavius lovianus Augustus (331-364), cesarz rzymski w latach 363-364. ${ }^{14}$ Flavius Theodosius (347-395), Teodozjusz I Wielki, cesarz rzymski od 379 r. oraz Teodozjusz II (ok. 401-450), cesarz wschodniorzymski, wnuk Teodozjusza Wielkiego. ${ }^{15}$ Flavius Arcadius (377-408), cesarz rzymski, syn Teodozjusza Wielkiego. ${ }^{16}$ Flavius Honorius (384-423), cesarz od 395 r., syn Teodozjusza Wielkiego. Inskrypcje, 0 których mówi Piramowicz, zaczerpnięte są z cytowanego dzieła Inscriptiones antiquae totis. ${ }^{17}$ Teodoryk Wielki (ok. 455-526), król 0strogotów od 471 r., utworzył państwo obejmujące: Italię, Sycylię, Dalmację, Recję, Norricum i część Panonii. ${ }^{18}$ Decjusz Cecyliusz (VNI w.), rzymski patrycjusz. ${ }^{19}$ Bonifacy VIII (ok. 1235-1303), Benedetto Gaetani, papież od 1294 r.
} 
i znowu pola zalane zostały. Marcin V Colonna ${ }^{1}$, jeszcze camerlingo ${ }^{2}$ będąc, był powołany na oglądanie bagn w roku 1417. Naradzając się z inżynierami, postrzegł, iż przeto inszych robót nietrwały był skutek, że wody długą drogą do morza prowadzone, niedostateczny miały spadek, chciał więc wprowadzić wody w Rio Martino, kanał z natury raczej niżeli ręką ludzką zrobiony. Ale robota nie mogła być uskuteczniona, nie tak przez śmierć papieża, jako przez przyrodzenie samej rzeczy: ponieważ nie wszystkie wody spadek tam mieć mogły, rznąc zaś głębiej wąwóz, ten między pagórkami, zdaje się rzeczą niepodobną dla niezmiernej roboty i niezmiernego kosztu. Rio Martino nie od Marcina V, ale dawniej tak zwany, ma szerokości na 35 do 45 stóp, a około 35 głębokości³. Groble albo raczej wzgórki po bokach jego na 15 albo 16 stóp wyżej są nad pola. Różni potym papieże wydawali rozkazy, obowiązując miasta Sezze i Terracina do wysuszenia pól swoich, ale stamtąd więcej przeszkody niż pomocy było. Leo $\mathrm{X}^{4} \mathrm{z}$ strony Ufentu rzeki wykopał wielki kanał Portatore zwany. Dał go krewnym swoim z przyległym gruntem pod małą daniną wosku do S. Piotra. Nazywa się jeszcze kanał Guiliano od brata Leonowego. Ten grunt przeszedł był do Francji. Na koniec, po różnych kupnach dostał się domowi książąt Gaetanich. Sixtus V znowu tę robotę przedsięwziął. Zastawił domowi Medicis część osuszoną, która ma trzy mile polskie w koło, a resztę im odebrał. Kazał przekopać wielki kanał nazywany fiume Sisto, gdzie zebrał znaczną część wód i ujście zrobił do morza niedaleko góry Circello, niedaleko terra oleola. Użył dawnych kanałów cesarskich, groble powysypywał. Po śmierci jego robota wniwecz poszła, częścią że za życia dzieła nie dokończył, częścią że kompanie, które się jemu podjęły były roboty i kosztu, kłócąc się między sobą, rzecz bez skutku zostawiły. Woda przez dwadzieścia sześć otworów rozlała się, groble pozrywała. Różni potym papieże jeździli tam sami, pozwalali osuszać, ustanawiali kompanie, jako mianowicie Urban VIII ${ }^{5}$ i Innocenty X ${ }^{6}$. Ale niezgody, opierania się mieszkańców, rybołówstwa przeszkadzały.

III. Pius VI papież dzisiejszy chwycił się był jako niegdyś Klemens XIII ${ }^{a}$ zamysłu około Rio Martino, ale przestrzeżono niepodobieństwo ${ }^{7}$. Niepodobieństwo jako jest wyżej namieniono, pochodziło stąd, że lubo jedne rzeki miałyby spadek dostateczny w przekop pagórków, drugie są niższe od niego, trzeba by zatem kopać go głębiej. Robota prawie niepodobna, bo rów wąski, ziemię wynosić w górę koszt i praca wieków. A do tego skutek mały, bo jedna strona by się tylko rzek ściągnęła, jedna część bagnisk osuszyła, jako na mapie widzieć można.

$\mathrm{Za}$ przestrzeżeniem tem niepodobieństwem papież dzisiejszy chciał jeszcze więcej o nim się upewnić i dowody tego złożył w archiwum i jak mówił: „położyć grobowy kamień temu przedsięwzięciu”. Wezwany był p[an] Rappini, człowiek mający dosyć teorii, a wiele doświadczenia, przez lat kilkanaście przy robotach około wód bonońskich ${ }^{8}$, temu zlecił papież, aby oglądał jeszcze stan Bagnisk Pontyńskich i sprawę z przejrzenia swego oddał, wysłany na tamte miejsce. W tem pokazane były słowa Strabona ${ }^{9}$, gdzie ten autor mówi, że jadący z Terraciny do Rzymu wsiadają w barkę i przez fosę bagnowemi i deszczowemi wodami napełnioną, ciagnnionie bywają od mułów, że zwyczajnie tę podróż nocą odbywają, spoczywając w barce, a rano na drogę apiuszową wysiadają. „Prope Terracinam qua Romam itur, iuxta viam Appiam Fossa longa ducta est, quae palustribus et fluvialibus impletur aquis, ac noctu maxime navidatur, ut qui navim vesperi intrant, mane egressi via Appia pergant. Sed et interdiu muli naves per eam fossam trahunt"b.

Zaraz papież napisał do Rappiniego, dając mu o tem znać. Z tych słów Strabona wziął on światło i umyślił szukać drogi apiuszowej, a zatem miejsca wzmiankowanego kanału, wnosząc, iż tamto

\footnotetext{
${ }^{1}$ Marcin V (1368-1431), Oddone Colonna, papież od 1417 r. ${ }^{2}$ Chodzi o funkcję kardynała kamerlinga. ${ }^{3}$ Stopa $=1 / 2$ tokcia małego; tokieć $=$ 24 cale $=595 \mathrm{~mm} .{ }^{4}$ Leon X (1475-1521), Giovanni de Medici, papież od $1513 \mathrm{r} .{ }^{5}$ Urban VIII (1568-1644), Maffeo Barberini, papież od $1623 \mathrm{r}$. ${ }^{6}$ Innocenty X (1574-1655), Giambattista Pamfili, papież od $1644 \mathrm{r}$. ${ }^{a}$ Klemens XIII mocno się był zabrał około tego zamysłu, kongregacją, czyli kommissją ku temu końcowi postanowit, ludzi biegłych w matematyce i hydraulice na zwiedzenie miejsca posyłał. Wszystkich jednomyślnie zdanie było, że wody spadek do morza mieć mogty, a zatem i bagna osuszone. Różne sposoby różni podawali. ${ }^{7}$ Klemens XIII (1693-1769), Carlo della Torre Rezzonico, papież od 1758 r. ${ }^{8}$ Por. La storia della bonifica. 9 Piramowicz miał na myśli dzieło Strabona Geographica. 0 tym sposobie podróży i w zwyż namienionem Horacjusza miejscu czytamy.
} 
położenie najniższe być musiało z całego okręgu bagnisk. Droga rzeczona tak błotem okryta i zalana była, że wątpiono, aby ją ciągle znaleźć można. Przedsięwziął zatem Rappini szukać wciąż drogi dla upewnienia o miejscu tego kanału. Częścią brnąc, częścią na płaskim bacie sandabo zwanym, mając przed sobą kilkudziesiąt ludzi, którzy drzewa, trzciny i insze zarośliny wycinali, wynajdował $\mathrm{z}$ trudnością miejscami drogę, ledwie mogąc czasem wiosłem błota też drogę okrywające zgruntować. Wziął się po tym do zważenia wody. Powiada, iż się przez te i inne doświadczenia upewnił, że miejsce to najniższe z całych bagnisk było i do najprościejszego układu ściągając umyśloną robotę, postanowił rznąć tam prosty kanał, który by złączywszy się z Pontatore, kanałem Leona X, wpadał w morze niżej Terraciny. W ten zaś kanał wprowadzić wszystkie poboczne rzeki i potoki, porobiwszy im rowy i koryta jak najprościejsze, a oraz odkryć dawną drogę, częścią Apiusza, częścią Trajana i w jak najprościejszą linią ją prowadzić ponad kanał. Kanał ten nazwano linea Pia. Zamysł takowej roboty roztrząśniony i potwierdzony został. Robota przed dwoma laty rozpoczęta. Najwięcej użyto pracy około wycinania drzew, znoszenia izbic i tam w rzekach i potokach dla rybołówstwa pozakładanych, około dobywania niezmiernych drzew i kamieni koryta rzeczone zawalających. Nie mniej było trudu i kosztu, żeby starą drogę Apiusza i Trajana ponaprawiać, porównywać i przerwy w niej porobione dla wybierania materiałów od tych, którzy się w okolicach murowali powypełniać. Zaczęto robotę od strony morza od chędożenia kanału przez Leona X zrobionego, a prawie cale zawalonego. Otworzywszy ten upust do morza, przedsięwzięto nowy kanał linea Pia. Robotnicy, brnąc w błocie i wodzie, musieli rznąć ten kanał, jako i teraz to czyniących widziałem.

IV. Stan roboty tegorocznej podczas mojej podróży był ten. Kanał Leona X przechędożony i bez przeszkód ujście do morza mający. Nowy kanał linea Pia zwany, z tamtym kanałem złączony, przekopany i zrobiony na mil włoskich 14, polskich około 3. Wody niektóre już w niego wprowadzone, bieg ma szybki, grunt twardy i po większej części kamieniami i cegłami z dawnych budowli zasłany, brzegi wysoko sypane, tak dalece, iż ostatniej zimy, bardziej nad inne dżdżystej, jeszcze wolne brzegi na łokci blisko 3 zostawały. Już tym kanałem spławiają drzewa do morza, skąd nie małą korzyść odbiera skarb papieski. Rzekom z gór płynącym, nim cały kanał dokonany będzie, rowy i spadki doczesne dane. Po prawej ręce kanału porobione co mila włoska rowy poboczne, któremi wody w kanał pryncypalny wpadają. Te rowy milowe odpowiadać mają kamieniom mile oznaczającym, które na nowej drodze nad kanałem stawiane będą. Kanał Piusa ciągnąć się ma od Ponte Maggiore, gdzie się z kanałem Leona X łączy, aż do Trepontum na mil włoskich 22, co wynosi na mil blisko pięć polskich. Szerokość łoża jego ku Forum Appium ma palmów ${ }^{1}$ 60, łokci polskich około $24^{2}$; a ku morzu za złączeniem z Portatorem ma palmów 180, łokci 67; od jednego zaś brzegu grobli do drugiego na przeciwnej stronie palmów 140, łokci 52 ku Forum Appium, a 310 ku morzu, łokci około 116. Spadek podług wziętej wagi wody z płaszczyzny pontyńskiej od Torre Treponti do morza palmów czterdzieści ośm, łokci ośmnaście. Właśnie teraz robiono około dalszego kopania tegoż rowu papieskiego. Robota znacznie sporo idzie, robotnicy na miarę płaceni. Przeszłego roku było ludzi na około trzy tysiące, tego na tysiąc, gdyż przeszłoroczna robota około wycinania lasów, trzcin, dobywania drzew, kamieni, robienia drogi nowej, więcej rąk wymagała.

Droga apiuszowa, niegdyś od Apiusza, najznaczniej od Trajana naprawiona, od Trepontum do Terraciny prawie miejscami z gruntu zepsuta, błotem i wodą pokryta była. Pobliscy mieszkańcy wiele stamtąd kamieni wybrali. Via Appia nie wszędzie szła w prostą linią. Pięć szarych rzymskich mostów znajduje się. Ten, który znaleziono na miejscu Fori Appii, według wszelkiego podobieństwa być musi jeszcze od Apiusza stawiony. Drugie są Trajana lub innych cesarzów. Trzy z tych mostów weszły w nową drogę. Fabryka tych mostów jako i droga przedziwna. Ubita była grobla na palach, kamienie klamrami żelaznymi spięte, bruk osadzony w masę z wapny i puccolany, czyli piasku z ziemi

${ }^{1}$ Palmo - starowłoska miara długości równa ok. 25 cm. ${ }^{2}$ Zob. przypis 3, s. 60 niniejszego tekstu. 
przepalonej podziemnemi ogniami ${ }^{\mathrm{a}}$. Pokopane były kanały i wody w nie ściągnione. Wszelkiej pracy w dzisiejszej robocie użyto, tak na znalezienie tej drogi, jako na dobywanie kamieni i gruzów. Dawna droga Apiusza i Trajana wąska była. Teraźniejsza częścią na dawnych fundamentach, częścią na nowych murowana, usłana jest kamiczkami z gatunku marmuru breccia po włosku, wygodniej niżeli dawny bruk, rowna, szeroka prawie na sto palmów, łokci polskich około trzydzieści siedm, mostami kamiennemi dająca przechód wodom i przejazd podróżnym: od miejsca, gdzie kanał Leona albo Juliana obraca się ku morzu, zrobiona już jest ku Forum Appium i trochę dalej, na mil włoskich około dwadzieścia cztery, polskich około pięć, prowadzona będzie linią prostą do Cisterny i wtenczas jej długość wyniesie na koło mil trzydzieści trzy. Od rzeczonego kanału Leona zasadzona jest na mil kilka drzewami, które z strony kanału we dwa rzędy idą, dla dania cienia pieszym.

Roboty, które zamierzają dalej wykonywać, są te: rzekom i potokom podawać łoża proste i najkrótsze do wielkiego kanału, inne rowy podług potrzeby dla spadku wód porznąć, mosty, gdzie przypadną, murować, drogę do Cisterny doprowadzić. Na istotne osuszenia dzieło zamierza sobie dyrektor ${ }^{1}$ lat dwie. Myślą po tym w Mezie miasto nowe założyć, ozdobne i kanałami otoczone, już niektóre budynki i piece na chleb pobudowane są, a w całym rozłogu tego pola inne domki postawiać dla rolników, na których się grunt podzieli, aby ich tym sposobem obowiązać do mięszkania przy swoich polach, dla lepszego onych uprawiania, skąd by utrzymanie kanałów, a za tym i całego dzieła trwałość nastąpiła.

W całym prawie ciągu nowej drogi i osuszonych pól widać pełno starych ruin i gruzów. Znakomitsze pamiątki dotąd znalezione są te: groby dwa $\mathrm{z}$ napisami mniejszej wagi, kolumna milowa z marmuru białego greckiego bardzo śliczna i w całości zachowana z napisem pięknym charakterem, podobna do tej, której napis jest u Grutera wyżej przytoczony [A]. Mosty w wyż wymienione.

Naprzeciwko Mezy, z drugiej strony dzisiejszego kanału, odkryto ruiny budynku ciagłego, z wielu izdebek składającego się: znać, że był portyk przed wejściem do tych izdebek, drzwi do izdebek z portyku były. Budynek ten musiał być na jedno piętro, gdyż kawałki murów pozostałe są bardzo cienkie, posadzki izdebek zasłane mozaiką z marmuru białego i czarnego, gładkiej roboty. Widać jeszcze na ściankach nieco koloru, które dziwna rzecz, iż przez tyle wieków w wodzie i błotach wystawały, po pod ściany znać, iż były rury albo rynsztoczki prowadzące wodę. Co wszystko największe czynią, że to były łaźnie publiczne. Prócz tego powiedziano mi, że kopiąc kanały, znaleziono wiele medalów czasów Rzeczyp[ospolitej]² oraz różne narzędzia domowe, które częścią oddano przełożonym nad Musaeum papieskim, częścią potrwoniono.

Mówiłem z dyrektorem, iżby można postawić w Mezie Musaeum Pometianum, w którym by złożono starożytności tam znalezione i do tamtego miejsca się stosujące; także kilka izdebek owych łazienkowych mniej zepsutych murem obwieść. Potym powiedziano mi w Rzymie, iż papież o rzeczonem Musaeum już był zamyślał.

Papież jeździł sam na oglądanie tego dzieła w kwietniu, dziwnie kontent z całej roboty, zwłaszcza iż okoliczność ustawicznych i niezwyczajnych deszczów, które bynajmniej brzegów kanału i grobli jego nie popsuły, ubezpieczyła go o dobroci i trwałości dzieła. Te swoje ukontentowanie wyraził obszernie w liście do kardynała Boncompagni³ ${ }^{3}$ legata bonońskiego, który mu nastręczył Rappiniego za dyrektora.

Koszt do czasu mojej podróży nie przechodził 200000 szkudów ${ }^{4}$, a dokonanie jej ze wszystkiem, podług rachunku dyrektora, nie będzie większy nad 500000 szkudów.

Były, jako w każdem znaczniejszem przedsięwzięciu bywać zwykły, przeciwności i zarzuty. Niektóre z nich już są uprzątnione, niektórych uprzątnienie od dalszego powodzenia zawisło.

\footnotetext{
${ }^{a}$ Tę drogę apiuszową nazywano reginam viarum. ${ }^{1}$ Był nim wspomniany powyżej Gaetano Rappini. ${ }^{2}$ Autor miał na myśli republikę rzymską. ${ }^{3}$ Ignazio Gaetano Boncompagni-Ludovisi (1743-1790), kardynat, legat papieski, sekretarz stanu Stolicy Apostolskiej w latach 1785-1789.

${ }^{4}$ Scudo - dawna złota lub srebrna włoska moneta o różnej wartości w zależności od kraju.
} 
Jako dawniejszych papieżów do tego dzieła zabierających się, tak i za tego największa przeciwność pochodziła od dzierżawców, którzy po różnych częściach Bagn Pontyńskich lasy trzymali albo zastawy na rybołówstwo porobili i z tych rzeczy dochód dość znaczny mieli. Przychodziło często dawniejszych czasów do gwałtu i bitwy z strony tych to dzierżawców przeciwko wysyłanym na osuszania. Dzisiejszy papież, idąc za powodem sprawiedliwości, taką względem tych, którym jako prawo w dzierżawie służyło, wziął drogę. Uwiadomiwszy się, jaki dochód z nich każdy miał, czyli z rybołówstwa, czyli z lasów i handlu drzewa, taką corocznie sumę płacić ofiarował, póki by dzieło osuszenia trwało. A gdy się dzieło szczęśliwie zakończy, obiecał tyle osuszonego gruntu dać każdemu, ile by przynosić mu równy dawniejszemu pożytek mogło. Ten postępek sprawiedliwości więcej u cnotliwych serc Piusowi VI chwały czyni, niżeli samo wielkie i rzymskim równe takowego dzieła przedsięwzięcie.

Celniejsze zarzuty przeciw tej robocie i odpowiedzi na nie od przełożonego nad osuszaniem są te: 1 . Złe powietrze tamtejszego kraju. Powietrze złe pochodziło $\mathrm{z}$ wód stojących, z błota i bagn. Za zniesieniem przyczyny pójdzie zniesienie skutku. Zamieszkanie ludzi, uprawa roli, utrzymywanie kanałów ubezpiecza dobroć powietrza i trwałość dzieła. 2. Tyle dawnych kanałów i samych portów zasypanych jest od morza piaskami, toż samo zagubi teraźniejszą robotę, choćby się udała. Na odparcie tego zarzutu, który jest najważniejszy, pokazuje dyrektor roboty, jak znacznie kanał wyższy jest od morza, jak woda z kanału wielkim pędem w morze wpada, tak dalece, iż w niemałej odległości od ujścia widać jej bieg szybki i kolor odmienny. A do tego myślą dla większego ubezpieczenia podawać inne, poboczne ujście wodom do morza, które by nie w jednej linii z pryncypalnym kanałem szły ku temuż morzu, a tak jeden wiatr i wzbieranie się morza nie będzie mogło różnym wyjściom szkodzić. Inszych, mniejszej wagi zarzutów nie wspomnę.

Po napisaniu tej wiadomości zdarzyło mi się dostać i czytać Latium Athanasii Kircheri. Autor ten znakomity biegłością fizyki i matematyki, kiedy za Innocentego X papieża zbierały się kompanie na osuszanie Bagn Pontyńskich, użyty był do roztrząania zamysłu tego i proszony o podanie swojego zdania, jeździł więc sam na miejsce, z wielką pilnością zwiedził je i osądził rzeczą być podobną osuszenie rzeczonych bagnisk. Ułożył zatem pismo, które czyni czwartą księgę dzieła wzwyż wzmiankowanego. W ciekawem tem piśmie przytacza zarzuty przeciwko podobieństwu przedsięwzięcia, zbija one, daje gruntowne przyczyny swego zdania i przepisuje sposoby, któremi rzecz wykonana być może.

Kircher imię Decennovium, którem nazwana jest droga Trajanowa, skądinąd wywodzi, aniżeli się w naszym opisaniu rzekło. Mówi on, że jest wzięte z nazwiska rzeki Ufens, które podług Prokopiusza $^{2}$ w księdze Rerum Gotticarum mianuje się Decennovius, przeto iż bieg jej od źródła do morza długi jest na mil dziewiętnaście.

Piękne i ciekawe jest świadectwo Teodoryka do senatu rzymskiego o przezorności i staraniach Cecyliusza Decjusza około wysuszenia Pontyńskich Bagnisk.

\section{Senatui Urbis Romae Theodoricus Rex}

Nir magnificus atque Patricius Decius glorioso circa Rempublicam amore devinctus, ultro postulavit voto mirabili, quod vix potuisset sub consilio nostrae pietatis imponi; paludem Decennovii in hostis modum vicina devastantem fovearum ore patefacto promisit absorbere illam famosam saeculi vasticatem, quam sub diuturnitate licentiae quondam mare palludestre possedit, cultisque locis inimicum superafundens unda diluvium, terrenam gratiam sylvestri pariter horrore confudit, nil utile nutriens sub liquore spoliatum fructibus est solum, postquam obnoxium capit esse paludibus. Ideo miramur privace confidentia Virum, ut quod diu virtus publica refugit, manus privata suscepaerit.

${ }^{1}$ Athanasii Kircheri è Soc. Jesu, Latium ${ }^{2}$ Prokopiusz z Cezarei (zm. ok. 562), historyk bizantyjski, uczestnik wojen toczonych przez Belizariusza przeciwko Persom, Wandalom i Ostrogotom, które też opisat. 
Hunc ergo audacem laborem gressurum se laudabili perfectione pollicitus est; ut pereunte damnoso gurgite, quae fuerant amissa ulterius non perirent; unde nostras sub hac parte fertilitatis postulat iussiones, ne sine authoritate publica, suberat opus eximium, quod erit cunctis viantibus profuturum. Sed vos Patres Conscripti praesentibus decretis adniumus, ut ad dicta lica Decennovii duos ex vestro corpore dirigatus, quibus arbitrantibus, quantum spatii restagnantis incusibus palludestris illuvies occupaverit fixis terminisadnotetur, ut quum ad perfectionem promissum pervenerit, liberatori suo reddita terra proficiat, nec quisquam inde aliquid praesumat attingere; quod tam diu invadentibus aquis non potuit vindicari ${ }^{1}$.

\section{Tegoż króla list do Decjusza}

Vobis itaque desideria iusta petentibus, praesenti authoritate concedimus, ut stagnis Decennovii paludibusque siccatis, sine fisco possideas in solum rura revocata; nec ullam inetuas libertatis rebus exhibere culturam, quas sub generalitatis testimonio absolvimus. Hinc etiam ad amplissimum Senatum praecepta transmisimus, ut definito nunc spatio ad tuum pulchre transeat dominium, quod est a faedis gurgutibus vindicatum, aequum est enim ut unicuique suus proficiat labor ${ }^{2}$.

\section{Starożytności Terraciny uważane w tej podróży}

Pokazują ruiny pałacu Galby ${ }^{3}$. Port Terraciny wystawiony przez Antonium Pium ${ }^{4}$, znaczne jego reszty. Widać dziury okrągłe w kamieniach, które służyły do przywiązywania okrętów. Port zasypany piaskiem, jak i inne dawne porty na tymże morzu. Pharos latarnia morska jest wieża rznięta w skale na sto dwadzieścia stóp wysokości, ozdobiona niszami i statuami, których nie masz; co dziesięć stóp od góry wyryte były litery dziesiątków z linią pod liczbami pociągnioną, od której do drugiej linii stopy liczyć się powinnya. We szrodku tej wieży skalistej jest wykucie od dołu w górę idące, przez które latarnia na wierzch windowana była. Jest kilka ruin kościołów rożnych, których z pewnością mianować nie można. Jest pod klasztorem Franciszkanów substrukcja ogromna z pięknych ciosowych kamieni rzniętych w boniaty ${ }^{5}$, złożonych bez żadnego wapnem lub czym innym spajania. Jest osobliwie dziwny akwedukt po większej w skale kuty, miejscami murowany, na mil włoskich pięćdziesiąt ciągniony, który podług gór krąży. Tym woda do Terraciny, gdzie na dobrej brakowało, prowadzona była.

\footnotetext{
1 Piramowicz nie podał źródła, z którego zacytował tekst tego listu. Mogło to być jednak dzieło, z którym zetknął się podczas włoskiej podróży: Nuova raccolta d'autori che trattano del moto dell'acque, vol. 6, Parma 1766, s. 260. ${ }^{2}$ Podobnie jak wyżej Piramowicz nie podał źródła tekstu. Znaleźć go można w zapewne znanej naszemu podróżnikowi książce: J. Peringskiöld, Vita Theodorici regis Ostrogothorum et Italiae, autore Joanne Cochlaeo Germano. Cum additamentis et annotationibus, quae Sveo-Gothorum ex Scandia expeditiones et commercia illustrant, Stockholm 1699, s. 549. ${ }^{3}$ Servius Sulpicius Galba (3-69), cesarz rzymski. ${ }^{4}$ Antoninus Pius (86-161), cesarz rzymski od $138 \mathrm{r}$. ${ }^{a}$ Niektóre tylko z tych dziesiątków zostały, inne z odłupaną skałą zginęly. ${ }^{5}$ Chodzi 0 konstrukcję boniowaną, znajdującą się pod zasadniczą budowlą.
} 


\author{
A. \\ $\mathrm{X}$. \\ IMP. CAES \\ DIVI. NERVAE \\ FILIUS NERVA \\ TRAIANUS. AUG. \\ GERMANICUS \\ DACCIUS. \\ PONT. MAX. \\ TRIB. POT. XIII \\ IMP. VI COS. V. P. P. \\ XVIIII SILICE \\ SVA PECUNIA \\ STRAVIT. \\ L. III \\ DDD. NNN. FFF. LLL \\ THEODOSIO. ARCADIO \\ ET HONORIC. P.P.P. FFF. \\ SEMPER. AUGGGG. \\ BONO. REIPVB. \\ NATUS ${ }^{a}$.
}

B.

DN. Gloriosiss. Adq. In

Clutus. Rex. Theodoricus Vicit.

Ac. Trif. Semper Aug. Bono Reip.

Natus. Custos Libertatis Et

Propagator Romani Nominis.

Domitor. Gentium

Decennovi. Viae Appiae Id Est A. Trip

Vsq. Terracenam. Iter Et Loca Quae

Confluentibus Ab Vtraq. Parte Paludum

Per Omnes Retretro Principum Inundaverant

Vsui Publico Et Securiati Viantium

Admiranda Propitio. Deo Feliciter

Deserviente Preconiis Ex Prosapia Decio

Rom. Caec. Man. Basilio Decio VC Et INI.

Ex PF. Vrb. EXPPO. EXCONS. Ord. Pat. qui Ad

Prepetuandam Tanti Domini Gloriam. Per.

Plurimos Qui Ante Non Erant Albeos...

.... Deducta In $\mathrm{Ma}$

Re Aqua Ignotae Atavi Et Nimis Antique

Reddit Siccitati.

${ }^{a}$ Grut. p. 1019 n. 15 Farb. dec. Fr. c. 9 p. $291 . \quad{ }^{\circ}$ Grut. p. 152 


\section{Bibliografia}

Aleksandrowska E., Grzegorz Piramowicz, w: Polski stownik biograficzny, t. 26, red. E. Rostworowski, Wrocław-Warszawa-Kraków-GdańskŁódź 1981, s. 529-536.

Casa R. i in., Assessing Crop Water Demand by Remote Sensing and GIS for the Pontina Plain, Central Italy, „Water Resources Management”, 23, 2009, s. $1685-1712$.

Dąbrowska M., Wtochy oczami podróżników rosyjskich czasów Oświecenia (Nikotaj Lwow i Jekatierina Daszkowa), „Rusycystyczne Studia Literaturoznawcze", 23, 2013, s. 11-21.

Enciclopedia dei papi, t. 3, Roma 2000.

Gawlik S., Grzegorz Piramowicz - idee, stowa, czyny, Opole 2006.

Grzegorz Piramowicz i jego epoka, red. K.A. Boreczek, A.A. Witusik, Kurów 2001.

Józef Wybicki. [Materiaty z sesji, Gdańsk 2-3 VI 1972], red. A. Bukowski, Gdańsk 1975.

Kowalczyk M.E., Obraz Wtoch w polskim piśmiennictwie geograficznym i podróżniczym osiemnastego wieku, Toruń 2005.

Mrozowska K., Grzegorz Piramowicz jako sekretarz Towarzystwa do Ksiag Elementarnych (17751787), „Studia i Materiały z Dziejów Nauki Polskiej. Seria A, Historia Nauk Społecznych”, 2, 1958, s. 162-200.

Pieczyński M., Jezuici a ars combinatoria. O poszukiwaniu uniwersalnej metody naukowej $w$ drugiej potowie XVII wieku (https://depot.ceon.pl/bitstre-
am/handle/123456789/3129/Jezuici-a-ars-combinatoria-repo.pdf? sequence $=1 \&$ is Allowed $=y$, dostęp: 16 kwietnia 2016).

Seppelt F.K., Löffler K., Dzieje papieży od początku Kościota do czasów dzisiejszych, t. 4, Poznań 2004.

Serva L., Brunamonte F., Subsidence in the Pontina Plain, Italy, „Bulletin of Engineering, Geology and the Environment", 66, 2007, s. 125-134.

La storia della bonifica pontina (www.bookomag. net/librarypdf/la-storia-della-bonifica-pontina-81274/, dostęp: 10 czerwca 2015).

Winiecki A., Drabiński A., Melioracje a ochrona przyrody - niezbędny kompromis, w: Ekologiczne aspekty melioracji wodnych, red. L. Tomiałojć, Kraków 1995, s. 107-121.

Zieliński Z., Papiestwo i papieże dwóch ostatnich wieków, Warszawa 1983.

Ziółek E.M., Grzegorz Piramowicz - teoretyk i praktyk pedagogiki polskiego oświecenia, w: Ars Educandi. Źródta, t. 1: Studia z dziejów wychowania $i$ ksztatcenia od średniowiecza do XIX wieku, red. J. Gwioździk, P.P. Barczyk, Mysłowice 2009, s. 264-273.

Ziółek E.M., Mistrz i jego mecenas. Stowo o wspótpracy Grzegorza Piramowicza i Ignacego Potockiego $w$ dziele edukacji ludu, w: Ród Potockich w odmęcie historii (XVII-XXw.), red. Z. Janeczek, Katowice 2007, s. 463-471.

Żywczyński M., Wtochy nowożytne 1796-1945, Warszawa 1971.

\section{Grzegorz Piramowicz's Account of Draining the Pontian Marshes during the Pontificate of Pope Pius VI}

\section{Summary}

The article discusses a little known text by the prominent Polish $18^{\text {th }}$-c. educator Grzegorz Piramowicz, in which the author refers to the process of draining the Pontian Marshes during Pope Pius VI's pontificate. Attempts to drain the region, located at the Tyrrhenian Sea, south of Rome, partially lying below sea level, were being made ever since the antiquity. The first surviving records are the Via Appia relics. Throughout the following centuries, subsequent Roman emperors and - from the Middle Ages onwards - popes were taking measures to drain this fertile land of Italia, acquire new areas for cultivation, and improve health 
standards so as to counter the recurring malaria epidemics.

In 1775 , as early as the first year of his pontificate, pope Pius VI started works which were aimed to fulfil this aim, digging up a new canal along the Via Appia (the so-called linea Pia). The canal was supposed to gather excess water from the marshes and direct them towards the sea. The plan also included setting up a port for Rome in Terracina, because originally the canal was designed to be floatable. The attempts, however, fell through, upset by the start of the French Revolution and the involvement of the Holy See in the conflict with France. Nevertheless, such a grand investment caused great interest across entire Europe. Among travellers and explorers who reached the site and described it was Grzegorz Piramowicz. He stayed in Italy between the years $1779-1780$, and in 1780 he made the trip through partially uncovered and reconstructed Via Appia to Terracina, with the Pope's chief engineer acting his personal guide, the Bolognese Gaetano Rappini.

Piramowicz's account is an extremely testimony not only of the Polish educator's interest in the endeavour, but also of his erudition. He began with presenting the geography and economic significance of the region and its history, placing special emphasis on all previous attempts to drain the marshes, from the times of Claudius Appius, throughout the reigns of the Roman emperors, up until the times of Theodoric the Great. Piramowicz drew on ancient literature available to him (i.a., Plinius, Strabon, Dionysius of Halicarnassus, Titus Livius, Plutarch, Svetonius, also poets - Virgil, Horace), as well as on works by his contemporaries such as
Inscriptiones antiquae... by Jan Gruter, Latium... by Athanasius Kircher, and quite likely, too: Vita Theo-dorici, regis Ostrogothorum... by Johannis Peringskiöld and Nova raccolta d'autori che trattano del moto dell'acque, vol. 6. Research query at many Italian libraries allowed him to describe efforts taken up to that time to drain the Pontian Marshes. In his description he briefly talks about works coordinated by popes beginning in the Middle Ages, whereas the main body of his text is devoted to efforts taken up by Pius VI and managed by Rappini.

Piramowicz acquired all his information directly from the papal engineer, which is made manifest by the included meticulous measurement data referring to the linea Pia that was under construction then. Importantly, as a humanist, he did not attempt to enter into polemics with the technical aspects of the project, preferring rather to follow the argumentation put forth by papal engineers and counsellors. He does devote quite a lot of space to discussions of many antique monuments which were excavated at the construction site. These he described with connoisseurship and admiration (e.g. the ruins of ancient bathhouses), expressing concern over their future. He did not fail to mention, for instance, the necessity to build a museum where these artifacts could then be preserved and presented. Piramowicz's account is concluded by a section of appendices from source excerpts - Theodoric the Great's letters to the Roman Senate and to Cecilius Decius, as well as two inscriptions, one with a quote by the king of the Goths, and the other earlier, from the times of Trajan.

Słowa kluczowe: osuszanie Błot Pontyjskich, pontyfikat Piusa VI, Grzegorz Piramowicz

Keywords: draining the Pontian Marshes, Pius VI's pontificate, Grzegorz Piramowicz

dr hab. Ewa Ziółek - profesor nadzwyczajny w Katedrze Historii XIX w., Instytut Historii Katolickiego Uniwersytetu Lubelskiego Jana Pawła II

(e-mail: ewamargo@kul.lublin.pl) 